\title{
A luta anticolonial angolana em Luandino e Pepetela
}

Resumo: Este artigo discute Lunanda e Nós, os do Makulusu de José Luandino Vieira e Mayombe de Pepetela, com base no contexto de luta anti-colonial em Angola a partir da 2a . Guerra Mundial. Inicialmente, é traçado um breve histórico sobre o ultracolonialismo português e sobre a trajetória da resistência angolana. Depois, são apresentados alguns autores fundamentais para o debate da autodeterminação dos povos do chamado Terceiro Mundo, como Balandier, Memmi, N'krumah e Fanon. Por fim, são trabalhadas estas três obras, escritas por dois intelectuais do MPLA, profundamente engajados na luta por libertação nacional.

Palavras-chave: Angola, imperialismo, literatura, resistência.

Summary: This article discusses Lunanda and Nós, os do Makulusu, written by José Luandino Vieira, and Mayombe by Pepetela, based on the context of anti-colonial struggle in Angola since the Second World War. Initially, it is outlined a brief history on the Portuguese Ultra-colonialism and on the Angolan history of resistance, then it presents some key thinkers, as Balandier, Memmi, N'krumah and Fanon, on the debate of the right of peoples from Third World countries to self-determination, and, finally, it analyses these three books, written by two intellectuals from MPLA, deeply engaged on the struggle for national liberation.

Key-words: Angola, imperialism, literature, resistance

\section{INTRODUÇÃO}

Em seu ensaio sobre literatura nos países subdesenvolvidos, Antonio Candido (1989) discute questões que podem ser diretamente relacionadas à produção literária em Angola. Neste contexto de hiperperiferia, o escritor não costuma pertencer à mesma classe social da maioria da população, em geral analfabeta, e é obrigado a escrever a um público estrangeiro, ainda que engajado na recuperação expressiva do país. Tal projeto de fundação da cultura nacional passa por diversas contradições. Além de recorrerem a um procedimento, a escrita, alheio ao grupo social que supostamente estariam representando (ainda mais num ambiente de tradição oral), estes escritores utilizam-se da língua do colonizador para afirmar a resistência e um projeto de país. Em África, deve-se acrescentar a dimensão da guerra e da violência no fazer literário e a consciência do escritor da não-universalidade de seu patrimônio cultural, sufocado pela hegemonia internacional do pensamento ocidental com base na filosofia greco-romana e na tradição judaico-cristã.

\footnotetext{
${ }^{1}$ Bacharel em Relações Internacionais pela PUC/SP e em História pela Universidade de São Paulo. Analista político do Instituto Ágora em defesa do eleitor e da democracia.
} 
Este artigo pretende discutir três livros angolanos, Lunanda e Nós, os do Makulusu de José Luandino Vieira e Mayombe de Pepetela, sob o enfoque da luta anti-colonial e de afirmação nacional. Inicialmente, será apresentada a conjuntura histórica que levou à organização de uma resistência revolucionária contra o ultracolonialismo português, na qual estavam inseridos estes escritores; depois, o debate travado entre os principais defensores da autodeterminação dos povos em sua perspectiva mais revolucionária de combate ao imperialismo; e, por fim, a literatura angolana de resistência, a qual busca debater não somente uma construção identitária, como também estabelece uma relação entre escrita e tradição oral.

\section{CONJUNTURA HISTÓRICA}

O fim da Segunda Guerra Mundial marca uma reordenação econômica e geoestratégica global com a ascensão de duas novas superpotências: a União Soviética e os Estados Unidos. No chamado "Terceiro Mundo", este processo se traduz na contestação ao neocolonialismo imposto pelos países europeus desde o final do século XIX, devido ao enfraquecimento político do continente no pós-guerra e ao estabelecimento de uma nova hegemonia internacional. Projetamse dois ideários distintos de defesa ao direito de autogoverno, existentes desde o fim da Primeira Guerra Mundial e associados a cada uma das duas novas superpotências. Os Estados Unidos fomentariam o idealismo liberal preconizado pelo presidente Woodrow Wilson, de defesa às chamadas "liberdades politicas", e a União Soviética difundiria o direito de autodeterminação dos povos numa base marxista de revolução popular antiimperialista.

No início do século XX, em África, a discussão sobre negritude, questão nacional e panafricanismo e a crítica ao neocolonialismo estavam limitadas às elites culturais locais, que sentiram diretamente a perda de seus privilégios com a chegada do colonizador europeu. O V Congresso Pan-Africano, realizado em Manchester em 1945, contou com a participação de estudantes, políticos e sindicalistas e trouxe uma mudança relevante neste cenário, sendo, por isso, considerado o mais importante. Além de rechaçar o racismo e o apartheid, conclamava a união contra o colonialismo e condenava o capitalismo, expondo a aproximação destas lideranças à concepção revolucionária de autodeterminação.

A disputa pela soberania articularia interesses e organizaria a solidariedade entre os continentes, dando origem a uma série de conferências internacionais. Destacam-se, neste momento de grande força do chamado "terceiro-mundismo", a Conferência de Bandung de 1955, a de Belgrado de 1961 e a Tricontinental de Havana de 1966. As reuniões não se limitariam, entretanto, a este conjunto de encontros intercontinentais, mas abririam um espaço para o 
concerto de organizações intracontinentais que pudessem coordenar as lutas nacionais, a partir de demandas propriamente africanas. A bipolarização mundial levaria no continente à formação dos grupos de Casablanca, no qual se destacavam Gana, Mali, Guiné-Conakry, República Árabe Unida (Egito) e Marrocos, e da Monróvia, liderado por Senegal e Costa do Marfim. Os primeiros defendiam o avanço na unidade política e econômica africana, além do apoio explícito à luta de libertação, e os últimos eram contrários à unificação em curto prazo, entendendo tal projeto como uma "intervenção", restringindo, pois, seu apoio à autodeterminação a uma "solidariedade política". Embora o nascimento da Organização da Unidade Africana (OUA), em Addis Abeba, no final do mês de maio de 1963, tivesse representado a dissolução formal destes blocos, as divergências entre os grupos permaneceriam por muito mais tempo.

Nesta época, Angola vivia os anos do ultracolonialismo. Ainda que a propaganda oficial difundisse uma suposta excepcionalidade do imperialismo português, baseada na proposta de Gilberto Freyre de um "luso-tropicalismo". O ultracolonialismo consistia na "modalidade simultaneamente mais extrema e mais primitiva de colonialismo" (ANDERSON, 1966, pag. 55). Para Perry Anderson, o trabalho forçado constituía a evidência máxima do atraso deste sistema.

Assim como França e Bélgica, Portugal estruturaria um sistema colonial extremamente hierarquizado e centralizado em nome da unidade do império. Para os países europeus, conforme sistematizado pelo ministro das Colônias francês Albert Sarraut em 1923, as colônias eram consideradas um mecanismo decisivo para as crises econômicas na metrópole e deveriam ser autossuficientes. E para tal, eram utilizados quatro mecanismos básicos: subvenções e meios de financiamento, confisco de terras, formas compulsórias de trabalho e cobrança de impostos.

Entretanto, em comparação com outras potências coloniais, o império português caracterizou-se por sua precariedade. Como reflete Anderson (1966), a Inglaterra aceitara reconhecer as pretensões lusas sobre a região do Congo nos anos 1880 só para conter o avanço belga e francês e porque considerava o "país de tal modo fraco que já contava como sendo zonas virtualmente suas aquelas que fossem reconhecidas como de dominio português" (ANDERSON, 1966, pag. 34). Enquanto as colônias de potências como França e Inglaterra foram o resultado da expansão imperialista do capital, as colônias portuguesas eram resquícios estagnados de feitorias, instaladas três séculos antes e ampliadas para o interior $^{2}$ pela ameaça de seus rivais europeus, particularmente pelas pressões inglesas e alemãs.

A ditadura de Salazar intensificou as contradições deste ultracolonialismo. A administração colonial ficou cada vez mais centralizada, sendo suprimida a relativa autonomia política e financeira dos "governadores" locais; houve um fortalecimento ideológico do darwinismo social

\footnotetext{
${ }^{2}$ Mesmo tendo avançado para o interior, a colonização portuguesa ficou concentrada no litoral.
} 
e do etnocentrismo, alimentando-se, assim, a justificação da tarefa missionária portuguesa de “educar" os "indígenas" (projeto assimilacionista ${ }^{3}$ ); estendeu-se o cultivo forçado, o qual, além de promover a fome em algumas regiões, intensificou o trabalho compulsório - referido eufemisticamente como "contratado" - e, com ele, a emigração clandestina, a coerção e a miséria. O Ato Colonial, de 1930, reafirmou oficialmente e estruturou a disposição lusa de dominação.

Além da importância econômica, as colônias constituíam parte relevante da construção nacional de um país cada vez mais isolado no cenário internacional (de tal modo, que Salazar afirmaria, nos anos 1960, que os portugueses estavam "orgulhosamente sós"). A partir da revisão constitucional de 1951, Angola não seria mais uma colônia, e sim uma "província ultramarina" de uma "nação una". Em outros termos, questionar o sistema colonial passaria a ser um crime de traição à pátria, uma vez que representava pôr em dúvida a integridade territorial do país.

Desde os anos 1930, devido à repressão e às péssimas condições econômicas na metrópole e à política lusa de povoamento (leia-se "de alívio demográfico"), a chegada de colonos a Angola foi intensificada. Este fenômeno revelaria ainda mais o precário nível de capitalização da colônia, já que, por esta contar com oportunidades muito limitadas de ocupação, produziu-se um considerável contingente de desempregados entre os próprios colonos europeus. Além disso, tal alteração demográfica representaria um retrocesso social para os "crioulos" - grupos que ocupavam importantes postos políticos, religiosos e militares, intermediários entre os europeus da metrópole e a maioria da população negra colonizada. Desde o final do século XIX, a penetração portuguesa já vinha sendo contestada por crioulos menos abastados, os quais passariam a ser preteridos nas nomeações para cargos que antes lhes representavam uma possibilidade real de ascensão social. Passariam, neste momento, a fazer críticas à capacidade real de uma metrópole tão frágil desenvolver Angola e ao favorecimento dos portugueses para postos locais. Não se propunha ainda uma confrontação mais radical à ordem social vigente: os questionamentos limitavam-se à reivindicação por reformas que lhes propiciassem o acesso a um setor privilegiado da sociedade local.

A partir da Segunda Guerra Mundial, a tímida contestação crioula passa a dividir-se entre uma linha reformista, de reivindicação de melhorias na legalidade por parte de uma intelectualidade crioula ligada às ideias mais antigas, e uma revolucionária, com uma perspectiva

\footnotetext{
${ }^{3}$ Socialmente, seria acentuada a já profunda desigualdade entre angolanos e portugueses, justificada pelo racismo articulado ao etnocentrismo (segundo os quais os negros seriam levados à "civilização" somente pelo trabalho) de natureza fortemente repressiva. Desta forma, a política cultural de assimilação era um mecanismo de incorporação que garantia a "conversão" gradual do africano em europeu, contanto que abandonasse sua cultura e se aproximasse aos costumes do colonizador. Seria estabelecida assim uma sociedade dividida em três: "civilizados", que compartilhavam dos direitos políticos da metrópole; "assimilados", percentualmente muito poucos que gozavam de algumas vantagens, mas rejeitados por brancos europeus e negros africanos; e "indígenas", maior parte da população, regidos pelo Estatuto do Indigenato que institucionalizava formas compulsórias de trabalho, fiscalização das condições de vida e aplicação de castigos corporais.
} 
voltada à libertação nacional e relacionada a intelectuais mais jovens. Em tal contexto, com o objetivo de recuperar um patrimônio africano relegado ao esquecimento pelas autoridades lusas, começa a haver um resgate cultural nacionalista. Este processo de valorização, intensificado no seio das associações culturais angolanas, estaria fortemente associado à movimentação revolucionária clandestina que se desenvolvia. E, por isso, travaria um diálogo intenso com o pensamento de orientação marxista e com a literatura modernista brasileira dos anos $1930^{4}$. Isso se traduz na fundação do movimento "Vamos descobrir Angola!" de 1948 e ao surgimento, em 1951, da revista Mensagem, editada pela Anangola (Associação dos Naturais de Angola). É importante destacar que ainda não existia um programa político definido neste primeiro momento, tratavam-se de pequenos grupos que buscavam ampliar a conscientização política e usá-la como base para uma atuação prática. Como entende Serrano, "o movimento 'Vamos descobrir Angola' representa na realidade uma retomada da iniciativa, uma recuperação da palavra dentro de um discurso angolano autêntico, mas, repetimos, ele aparece ainda de uma forma fragmentada" (SERRANO, 2005, pag. 147). As discussões sobre a situação colonial e a autonomia nacional, o contato com a literatura política chinesa e soviética e a leitura de revistas e livros brasileiros que chegavam clandestinos à Angola seriam fundamentais para a formação das novas gerações de escritores angolanos.

Deve-se enfatizar que a resistência em Angola não se limitaria ao espaço colonial. Nos anos 1920, seriam criados, em Lisboa, a Liga Africana e o Partido Nacional Africano, os quais defendiam um "regionalismo africano", evitando o emprego da palavra "nacionalismo". Diferentemente da palavra de ordem “África para os africanos" do I Congresso Pan-Africano (1919), o presidente da Liga Africana defendia, à época, "uma cooperação leal entre brancos e nativos numa base equitativa, numa palavra - a Africa também para os africanos" (MAGALHÃES, 1921 apud HERNANDEZ, 2005, pag. 521). Nesta época, existia também um grupo de intelectuais do continente, tanto estudantes quanto trabalhadores, que se reuniam em torno da "Casa da África".

Devido à impossibilidade de continuidade dos estudos nas colônias pela ausência de instituições de ensino superior, uma parcela dos estudantes não somente de Angola como também de Moçambique, Guiné-Bissau etc, prosseguia sua formação em Portugal. De maneira geral, em Angola, os crioulos de Luanda e do interior próximo a esta cidade (no eixo LuandaMalange) eram os que tinham condições, com recursos próprios, de pagar a viagem e sua manutenção na metrópole. Havia também a possibilidade também de conseguir bolsas de estudo, patrocinadas em sua maioria pelas missões protestantes.

\footnotetext{
${ }^{4}$ Como observa Antonio Candido (1989), esta literatura é marcada por uma intensa compreensão político-social sobre a condição de subdesenvolvimento do país, atribuindo as dificuldades vividas no cotidiano ao meio social e não a defeitos inerentes aos personagens.
} 
O ambiente pouco acolhedor de Portugal levaria à criação de centros de reunião entre os estudantes das mais diversas colônias, o que preocuparia o governo salazarista e conduziria à criação da Casa dos Estudantes do Império (CEI), em meados dos anos 1940. Além do suporte material, a CEI impulsionaria a promoção de eventos culturais e atividades que facilitassem a socialização estudantil (cabe colocar que os bolsistas angolanos, geralmente fora do eixo crioulo, não costumavam freqüentar a Casa). Ao agrupar estes estudantes das diversas colônias em um só espaço, a repressão portuguesa julgava que o controle de suas atividades, no caso, pelo Ministério das Colônias auxiliado pela conservadora Mocidade Portuguesa, seria facilitado. Entretanto, a maior parte deles já estava no Movimento Unidade Democrática e a CEI tornar-se-ia um espaço de difusão e discussão das ideias anticoloniais, com fortes ligações à oposição lusa. A busca pela "reafricanização dos espíritos" e a valorização da "verdadeira identidade", pautadas pela crítica contra o fascismo, levou a Casa a ser o berço dos principais quadros da luta por independência nacional.

Deste modo, em Angola, a resistência anticolonial mais revolucionária formou-se a partir de correntes nacionalistas da colônia (“os do interior”) e de outros países da Europa e, em menor escala, da África (“os do exterior”). De acordo com Bittencourt (1999), a junção do Partido da Luta Unida dos Africanos de Angola, o PLUA, com outros grupos nacionalistas para a formação do Movimento Popular de Libertação de Angola (MPLA) deu-se no início de 1960. A tática de guerra adotada pelo movimento seria o revezamento do aspecto diplomático (geralmente concertado no exterior) e militar (realizado na colônia), dependendo da conjuntura de maior ou menor repressão pela PIDE (polícia portuguesa instalada em Angola desde 1957). Esta interdependência político-militar aplacaria as limitações tanto dos grupos internos, os quais não seriam capazes de crescer se não houvesse este suporte estrangeiro, quanto dos externos, que, por seu afastamento, não tinham um conhecimento conjuntural tão detalhado do conflito. O MPLA seria inicialmente constituído por militantes kimbundus, oriundos de Luanda e de algumas cidades ao sul, com formação no exterior, o que levava seus opositores da União das Populações de Angola (UPA) a taxá-lo de um movimento de mulatos intelectuais e urbanos ("filhos de colonos"). Quando sua base mudou de Conakry para Leopoldville, onde se encontrava há muito tempo a organização inimiga de Holden Roberto (UPA), houve uma alteração neste perfil e recrutaram-se pessoas de outras realidades socioculturais.

Além deste - e também oposto a ele -, existia outro grupo anti-colonial, formado em 1957 ao norte, composto por emigrantes angolanos situados no então Congo Belga e unidos por associações semi-secretas de raiz bakongo, a já citada UPA. As lideranças angolanas bakongo tinham um perfil muito distinto dos quadros políticos crioulos do MPLA: o processo de 
urbanização da região era mais recente, o que levava a uma ligação maior com o campo e, ao mesmo tempo, estavam mais distantes do aparelho colonial português. Outro aspecto de diferenciação era a formação: no Congo belga, a escolarização primária era mais difundida e raramente se chegava ao ensino secundário, ao passo que, em Luanda, alguns poucos logravam chegar à formação universitária. Além disso, a luta no Congo belga tomaria formas raciais mais acentuadas, o que dificultaria a penetração dos membros do MPLA. Com a ampliação da ajuda exterior, Holden Roberto ganhou mais espaço na UPA e logrou difundir a imagem de ser este um movimento de camponeses, embora sua direção fosse composta por famílias influentes e urbanizadas do norte da colônia. Em 1962, a UPA se associaria ao pequeno Partido Democrático de Angola (PDA) e passaria a se chamar Frente Nacional de Libertação de Angola (FNLA). No plano internacional, ela se enquadraria no grupo de Monróvia e Holden Roberto lograria o apoio do Congo de Mobutu, da China e dos Estados Unidos. Em 1966, haveria uma cisão na frente que daria origem à União Nacional para a Independência Total de Angola (Unita), apoiada pelos ovimbundos e principal rival do MPLA, a partir de 1975.

No dia 04 de fevereiro de 1961, há o primeiro choque mais significativo contra Portugal, a partir dos ataques, reivindicados pelo MPLA, a algumas prisões de Luanda. Apesar de seu fracasso militar, a operação ganhou muita visibilidade e forte peso simbólico. Em 15 de março, houve outra revolta agora no norte da colônia, realizada pela UPA e marcada por uma profunda violência. Estes dois acontecimentos marcariam o início "oficial” da guerra de libertação angolana.

\section{A LUTA ANTICOLONIAL EM DEBATE}

Nos anos 1950 e 1960, devido ao crescimento do "terceiro-mundismo", muitos grupos e indivíduos progressistas postulariam contestações profundas contra o imperialismo e defenderiam a autodeterminação dos povos. Por imperialismo, entende-se o conceito trabalhado por Lenin (1979) do capitalismo em sua fase monopolista, em que o poder político-econômico está nas mãos do capital financeiro e todas as regiões do planeta estão subordinadas e são disputadas por poucas potências dominantes. Trata-se de um fenômeno diretamente ligado ao desenvolvimento das contradições estruturais do capitalismo, levando à sua transformação de um sistema baseado na livre concorrência a um baseado no monopólio. 
$\mathrm{Na}$ fase imperialista do capital, a partilha do mundo entre as grandes potências faz-se necessária ao monopólio pela grande concentração econômica a que este chega ${ }^{5}$. Seus objetivos são a busca por novos mercados para escoamento das suas mercadorias, já que o sistema se caracteriza pela superprodução; a exportação dos capitais excedentes para o estrangeiro, intensificando as relações político-econômicas entre países explorados e exploradores; e a colonização direta sobre possessões coloniais, as quais garantem mercado consumidor, matériasprimas baratas, local de envio de excedentes populacionais da metrópole e localização geoestratégica relevante, já que, muitas vezes, encontram-se distantes do hemisfério das potências que as colonizam. Lenin (1979) entende que, nesta fase, quando o capitalismo apresenta-se politico-economicamente tão forte, é um momento em que está mais agonizante, pois suas contradições estão mais agudas e escancaradas. Stalin acrescenta:

“o imperialismo é a exploração mais descarada e a opressão mais desumana das centenas de milhões de habitantes das imensas colônias e países dependentes. O objetivo desta exploração e desta opressão é a obtenção do excesso de lucro. No entanto, ao explorar esses países o imperialismo vê-se obrigado a construir neles estradas de ferro, fábricas e oficinas, centros industriais e comerciais. O aparecimento da classe dos proletários, a formação de uma intelectualidade no país, o despertar da consciência nacional, o incremento do movimento de libertação são outros tantos resultados inevitáveis desta 'política"' (STALIN, 1979, pag. 14).

Stalin (1979) reflete que a libertação nacional é de fundamental importância para o marxismo por representar uma possibilidade real de enfraquecimento estratégico do imperialismo. Para ele, não se deveria desconsiderar tampouco o potencial de uma luta anticolonial se transformar numa revolução socialista, mas isso depende da liderança efetiva da classe trabalhadora.

Ao encontro desta linha, Discurso sobre o colonialismo (Césaire, 1971) pondera que, no imperialismo, a contradição interna entre burguesia e proletariado e o problema colonial tornamse cada vez mais escancarados, revelando a hipocrisia dos auto-proclamados defensores da "civilização" europeus e tornando suas práticas indefensáveis. Ao negar a humanidade do “indígena” - coisificando-o - e travar com ele relações de domínio e submissão, o colonizador acaba por se embrutecer e desumanizar. Pelos fortes laços estabelecidos com o fascismo e pelo estímulo ao discurso racista de "raças superiores" e "raças inferiores", Césaire defende que

\footnotetext{
${ }^{5}$ Esta partilha não se dá de forma pacífica, pelo contrário, há uma luta entre estas grandes potências pela possessão monopolista de colônias - novas repartições num mundo já dividido, disputas por novos grupos financeiros e novas potências contra impérios e grupos antigos que insistem em manter suas conquistas etc. Com isso, as guerras imperialistas tornam-se inevitáveis.
} 
"ninguém coloniza inocentemente, e também ninguém coloniza impunemente" (CÉSAIRE, 1971, pgs. 17). Ao apontar o processo de "barbarização" da burguesia, alega que esta é uma evidência de que seu inevitável desaparecimento está próximo.

Georges Balandier (1993) propõe a compreensão da situação colonial como uma totalidade, levantando as contribuições aportadas por diversos campos de conhecimento (história, economia, etc) sobre o tema e rechaçando interpretações unilaterais que, ao desconsiderá-lo, tendem a uma abordagem empirista rasa (imediatista). Ele parte da definição de colônia de H. Laurentie como sendo "um país onde uma minoria europeia se sobrepôs a uma minoria nativa de civilização e de comportamentos diferentes; esta minoria europeia age sobre os povos autóctones com um vigor desproporcional ao seu número; ele é, se quisermos, extremamente contagiosa (sic) e, por natureza, deformante" (LAURENTIE, 1944 apud BALANDIER, 1993, pag. 116). Ainda que fosse numericamente uma minoria, o colonizador europeu estabeleceu-se, com base em sua superioridade material e num sistema estruturado na desigualdade entre colonos e colonizados, como agrupamento dominante, tornando os "indígenas" uma minoria sociológica.

No que diz respeito ao "contato" entre as culturas, há uma forte crítica ao funcionalismo de Malinowsky, que limita sua abordagem ao instante do contato cultural, desconsiderando a dinâmica histórica e as contradições sociais do colonialismo. Por este motivo, sua análise não apreendia, de maneira satisfatória, a forma pela qual os fenômenos culturais eram condicionados pelos conflitos coloniais ou o levava a minimizar a real significação do movimento anticolonial. Uma abordagem que se pretenda completa precisa levar em consideração a situação colonial e sua crise estrutural:

"diversos trabalhos (em geral os mais polêmicos) insistiram, ao contrário, sobre o estado de crise que revela a maior parte das sociedades colonizadas. O que é verdadeiro na medida em que a minoria dominante se opõe às verdadeiras soluções; porque é bem evidente que no caso da sociedade colonizada, $a$ busca de suas normas modernas coincide com a busca de sua autonomia. Este fato impõe ao sociólogo um método de análise de alguma maneira clínico. E mostramos, num estudo antigo, como o exame das sociedades colonizadas, pelo viés de suas crises específicas, permite o acesso, sob certos pontos de vista, a 'uma posição privilegiada'. Tais crises colocam em causa a quase totalidade da sociedade, tanto as instituições quanto os agrupamentos e os símbolos sociais” (BALANDIER, 1993, pag. 123).

Para ele, a descolonização alterou a prática científica, com obras fortemente marcadas pela militância política, problematizando contundentemente a perspectiva estática adotada pela antropologia até aquele momento. Fanon, por exemplo, em Condenados da Terra (1961) discute como a revolução acelera as transformações da sociedade antiga e leva ao desaparecimento das condutas sociais tradicionais. 
O objetivo de Balandier é reconhecer o caráter heterogêneo desta sociedade, entendida como uma estrutura historicamente determinada, de modo a permitir o desenvolvimento de uma investigação social dinâmica. Enquanto sua abordagem é mais teórico-metodológica, pensadores como Memmi, N'krumah e Fanon buscavam dialogar diretamente com os movimentos anticoloniais africanos.

Memmi (1967) reflete que não existe um europeu na colônia sem vantagens, já que, mesmo considerando que nem todo colono seja um grande detentor de posses, o privilégio está sempre presente. Por ser impossível o colonizador não se aperceber desta sua situação, há duas atitudes que pode tomar: ou se recusa a aceitar sua condição ou se aceita um colonialista.

No primeiro caso, há uma grande dificuldade na manutenção de sua posição, pois o que o leva a se aproximar destes movimentos é uma ideologia humanista de esquerda, que se confronta, muitas vezes, com a tática do terror a que pode recorrer o colonizado ou com bandeiras de libertação religiosas. Se aceitar mesmo assim que isso diz respeito ao colonizado e que a colonização e o imperialismo são em si piores, pode-se tornar um trânsfuga, identificando-se completamente com a causa emancipatória. De qualquer forma, deverá conviver com a justificável desconfiança do colonizado e sua capacidade de atuação acaba por ficar seriamente comprometida.

No segundo caso, o colonialista finge ignorar a miséria e reivindica a dominação imperial. Para Memmi, trata-se, via de regra, do caminho natural de qualquer colono, embora tal "escolha" não se dê tampouco sem dificuldades, já que, ao admitir-se dominante, não escapa ao colonialista seu papel de usurpador, o que o faz querer legitimar tal privilégio. Para isso, engrandece, por um lado, seus méritos e canta loas à metrópole e, pelo outro, inferioriza cada vez mais o colonizado, razão precípua de seu desconforto. Porém, quanto mais nega o colonizado, oprimindo-o, mais afirma seu papel de explorador e aumenta o desprezo de si. Para justificar sua posição, tende então, cada vez mais, ao fascismo, defendendo incondicionalmente a opressão de pessoas tão abjetas e num lugar tão inferior. A condição de inferioridade do colonizado passa a ser colocada como uma característica natural (a impossibilidade do "indígena" governar a si mesmo) e o racismo se torna estrutural a toda situação colonial, generalizando um retrato mítico do colonizado como preguiçoso, brutal, covarde etc. Enfim, como sintetiza Memmi,

“o colonialista não é, em suma, senão o colonizador que se aceita como colonizador. Que, em consequência, explicitando sua situação, procura legitimar a colonização. Atitude mais lógica, efetivamente mais coerente que a dança atormentada do colonizador que se recusa, e continua a viver na colônia. Um tenta, em vão, pautar sua vida por sua ideologia; o outro sua ideologia pela sua vida, unificar e justificar sua conduta. Em resumo, o colonialista é a vocação natural do colonizador" (MEMMI, 1967, pgs. 51 e 52). 
O colonizado não é insensível à desumanização e à mistificação: de alguma forma, aceita o estigma que recai sobre si, confirmando seu papel subalterno no sistema colonial. Para haver uma situação de dominação, não bastam as relações objetivas: é necessário que se legitime a opressão, ou seja, o colonizador precisa ser reconhecido pelo colonizado. Este não tem direito algum, não se sente sujeito real de sua história, decidida pela administração do colonizador e, portanto, o colonizado não tem nenhuma experiência de nacionalidade ou de cidadania. Esta carência social é passada de geração em geração: o pai colonizado não transmite a dimensão de uma cidadania não vivida ao seu filho e no momento em que este, adolescente, se revolta contra a família não pode sadiamente resolvê-lo no conflito social, a menos que resolva questionar absolutamente a estrutura dominante. Por isso, a tendência, diante do imobilismo, é o recuo aos valores tradicionais e, consequentemente, a petrificação da sociedade colonizada. Devido à ausência de instituições próprias e de uma educação que recupere a História de seu povo, o colonizado está condenado a perder a própria memória e a não testemunhar nada, durante sua existência, que possa ser guardado pela consciência coletiva. A sensação de ser um estrangeiro em seu próprio território é constante, uma vez que sua língua materna, aquela na qual se dão suas relações emocionais, é menos valorizada do que outra, uma língua europeia da metrópole, que pauta todas as instituições coloniais. Enfim, o fato de o colonizador limitar a colônia a uma provedora de matérias-primas leva a um reforço da política de não-industrialização e a um desenvolvimento técnico arcaico, intensificando a privação do colonizado e tornando-o um "ser de carência".

Diante desta situação, o colonizado pode aceitar o sistema e tentar ainda igualar-se a este "modelo de sucesso", o colonizador, ou recusá-lo profundamente até o ponto de lutar pelo resgate de si e de seu povo. No primeiro caso, a admiração ao colonizador e a aceitação do colonialismo implicam a recusa da própria identidade por meio da assimilação. Depois de pagar um preço exorbitante para esta "transformação", descobre, porém, a inutilidade de sua tentativa, já que não basta afastar-se do seu grupo, é necessário penetrar em outro e, neste caso, há uma recusa direta por parte do colonizador. Ainda que alguns colonizados tenham conseguido de fato ingressar no grupo dos colonizadores e se confundir com eles, a assimilação nunca foi um projeto geral, pois implicaria o fim do colonizado e, logo, do colonizador. O colonialismo é estrutural e suas contradições não podem ser resolvidas por algumas saídas individuais, a única solução é a negação da colonização como um todo. Com isso, entra-se no segundo caso: a revolta contra o sistema colonial, a única saída possível para um colonizado (frente a uma situação de opressão absoluta, a única solução possível é a ruptura). A reconquista de si mesmo e a resistência à dominação conduzem à recusa do colonizador e aqui Memmi atenta ao fenômeno do "racismo 
do colonizado", a recusa em conjunto de todos os europeus das colônias, tidos como colonizadores. Entretanto, a diferença do racismo do colonizado em relação ao do colonizador é que este se fundamenta numa mistificação do "indígena” que só serve para intensificar sua dominação e aquele parte de uma situação histórica concreta de ressentimento e resistência contra a dominação. Há a necessidade, então, de um resgate de suas tradições e sua consequente valorização, mesmo que isso implique levantar representações que parecem paradoxais para grupos progressistas, como o retorno à religião. Memmi conclui sua reflexão defendendo que a crise do colonialismo não é um desejo, mas uma constatação. De acordo com ele, “a acomodação não poderia ocorrer porque era impossivel. A colonizaçãa contemporânea traz̧ia em si mesma sua própria contradição, que cedo ou tarde deveria fazêe-la morrer" (MEMMI, 1967, pg. 122).

Memmi não analisa, entretanto, os diferentes interesses que possam existir dentro de um mesmo movimento nacional. Neste caso, retornando a Lênin no texto Sobre o direito das nações à autodeterminação de 1914:

"Na medida em que a burguesia da nação oprimida luta contra a opressora, nessa medida nós somos sempre e em todos os casos e mais decididamente que ninguém a favor, pois nós somos os inimigos mais audazes e consequentes da opressão. Na medida em que a burguesia da nação oprimida defende o seu nacionalismo burguês, nós somos contra. Luta contra os privilégios e as violências da nação opressora e nenhuma tolerância para com a aspiração aos privilégios por parte da nação oprimida" (LENINE, 1979, p. 523).

Como postula Vladimir Ilich Lênin, os revolucionários devem apoiar as lutas de libertação nacional, sempre quando estas se dão contra a opressão de países mais poderosos. No entanto, quando a burguesia nacional passa a se utilizar desta bandeira para conquistar privilégios de classe, os comunistas devem se opor às suas aspirações. O problema é que não há um limite evidente em relação a esta passagem, ou melhor, não está claro quando começa uma luta e termina outra para um espectador externo.

N’krumah (1967), por sua vez, advoga que o capitalismo, nos países desenvolvidos, abandonou dois princípios que o caracterizavam: a subjugação das classes oprimidas e a exclusão do Estado da atividade econômica. Depois da Segunda Guerra Mundial, devido às pressões internas contra a manutenção da intensa contradição que caracterizou as metrópoles no período anterior, teve-se que adotar o Welfare State. Para financiar este modelo, houve uma intensificação 
da exploração neocolonial. ${ }^{6}$ Entretanto, isso representou uma mera exportação de um problema interno, o conflito entre ricos e pobres, para o plano internacional (o perigo maior não seria mais uma guerra civil, mas um conflito mundial). Ao fazê-lo, os capitalistas limitaram-se a adiar uma crise inevitável e, pior, aumentaram-na, pois sua causa, a ação sem controle do capital, não foi resolvida. Para manter o Estado de bem-estar na metrópole e, ao mesmo tempo, sustentar os gastos consideráveis com armamentos para manutenção do grande complexo financeiro sob seu controle, estas potências desejarão explorar ao máximo suas colônias. O único meio efetivo de desafiar este império econômico é a ação pan-africana por meio de um governo unido. Nenhuma potência concedeu a independência a uma colônia unilateralmente. Os países africanos só se libertaram quando houve uma guerra de libertação ou quando a própria organização anti-colonial estava tão forte que qualquer tentativa de resistência à independência tornava as consequências político-econômicas de uma guerra colonial muito desvantajosa. A unidade africana permitiria a estruturação de um contrapeso suficientemente forte para conter tais tentativas imperiais. " $O$ perigo para a paz, mundial surge, não da ação dos que procuram acabar com o neocolonialismo, mas da inação dos que permitem que continue" (N'KRUMAH, 1967, pag. 306).

Apesar de N'krumah estar certo ao defender que a manutenção do Estado de bem-estar só foi possível devido à exploração de terceiros, é um equívoco considerar que as metrópoles simplesmente abandonaram a subjugação de sua classe trabalhadora e que o conflito passou a se limitar ao plano internacional. Se houve um abrandamento na exploração do operariado nas potências, este se deveu à destruição dos fatores de produção na guerra e à forte organização da classe trabalhadora durante o período. Porém, isso não implica que o capitalismo tenha dissolvido sua contradição intrínseca nestes países, apenas que a mais-valia extraída era menor.

Fanon (2006) está de acordo que a única saída contra esta "violência atmosférica" que caracteriza todos os sistemas coloniais é a resistência pela força das massas colonizadas. Devido a um processo alienado de "epidermização" do complexo de inferioridade e decorrente da sensação de impotência sentida na sociedade colonial, o "indígena" acumula uma "raiva vulcânica", liberada, num primeiro momento, na dança, no exorcismo, no transe e na violência contra seus pares. A única forma de se libertar efetivamente é voltar toda esta violência colonial contra o colonizador, que a utiliza não somente para controlar o colonizado como também para desumanizá-lo. O problema é que os movimentos políticos de libertação, que deveriam ser responsáveis pela organização deste processo, adotam táticas e/ou estratégias equivocadas. Em

\footnotetext{
${ }^{6}$ N'krumah reforça que, antes da guerra, havia, em alguns momentos, uma real identificação dos partidos da classe operaria na metrópole com os povos coloniais e no momento em que se estruturou o Welfare State muitos dos líderes daquela classe operária aceitariam e/ou adotariam o recrudescimento da política colonial. Ho Chi Minh também atenta à indiferença do proletariado da metrópole em relação à questão colonial e seu profundo desconhecimento do problema, de maneira geral.
} 
alguns casos, não passam de partidos eleitoreiros que rechaçam o uso da violência. Aqui Fanon aproxima-se da crítica de Lênin (1979) ao social-chauvinismo dos partidos ligados à Segunda Internacional, um oportunismo reformista entendido como a associação, a colaboração de classes, entre a aristocracia operária e a burguesia, que conduz necessariamente ao abandono da perspectiva revolucionária. Além disso, o público destes agrupamentos nacionalistas, mesmo os sinceramente revolucionários, é o operariado urbano, que limita suas reivindicações à melhoria política e econômica de sua situação sob o colonialismo. Para Fanon, o campesinato colonial, por viver em sociedades mais tradicionais que conseguem manter uma organização comunitária e disciplinada, é neste contexto a classe social revolucionária (sem possibilidade de acordo com a ordem dominante). Pelo fato de a disposição de luta da grande maioria ser irreversível, apela-se à repressão, a qual só faz aumentar esta mesma resistência. Ao preconizar a violência do oprimido como resposta à violência do opressor, ele se aproxima de Mao Tse-Tung e de Vo Nguyen Giap em seu conceito de "guerra popular". De acordo com Giap,

“empreendemos uma guerra do povo no âmbito de um país colonizado por longo tempo. O fator nacional, foi, portanto, de importância primordial; era preciso congregar todas as forças suscetíveis de derrubar os agressores e seus aliados. Essa guerra, por outro lado, se desenrolava em um país agrícola atrasado onde os camponeses, que representavam a grande maioria da população, constituíam as forças essenciais da Revolução e da Resistência" (GIAP, 1968, pg. 42).

\section{LITERATURA ANGOLANA E RESISTÊNCIA}

A literatura anticolonial e de afirmação nacional angolana é desenvolvida a partir do movimento "Vamos descobrir Angola!". Em sua maioria, são escritores pertencentes ao MPLA, o que, por um lado, levaria a uma relação direta do texto com a causa revolucionária, mas, por outro, colocaria um problema até hoje existente de uma formação nacional estreitamente vinculada a este partido político. Além da presença marcante do marxismo nesta produção literária, alguns escritores, como Viriato da Cruz, desenvolveriam uma escrita oraturizada e oraturizante para registrar a apropriação deste "instrumento" europeu por uma cultura baseada na tradição oral. Como coloca Manuel Rui, "não posso matar o meu texto com a arma do outro. Vou é minar a arma do outro com todos os elementos possiveis do men texto. Invento outro texto. Interfiro, desescrevo para que conquiste a partir do instrumento escrita um texto escrito meu, da minha identidade" (MONTEIRO, 1987, pag. 28).

Memmi trabalha o bilinguismo colonial como um drama e acredita que a opção pela língua do colonizador condena a literatura colonizada a morrer jovem, pelo dilaceramento pessoal de 
um escritor condenado a escrever num idioma que não é o de seu povo (e, mesmo se o fizesse, não poderia ser lido devido à grande quantidade de iletrados). Na literatura angolana de língua portuguesa, isso não se verifica: tratam-se de escritores formados por uma literatura estrangeira, a brasileira, que interferem no português de modo a oralizá-lo e até "kimbundizá"-lo. Luandino trava um interessante diálogo com João Guimarães Rosa: como o escritor mineiro, não se limita a fazer um registro do falar regional, mas o recria como algo novo, a fim de buscar uma conscientização do leitor sobre a linguagem, elevar o kimbundu e "desautomatizar" a leitura. Em outros termos, não se contenta simplesmente em escrever palavras na língua local, mas utilizar sua estrutura linguística para subverter e dominar o português.

A relação entre a tradição oral e a literatura não se limita a esta "subversão linguística", há uma tensão no próprio gênero. O poema e o conto tendem a ser privilegiados em detrimento do romance, gênero por excelência de civilizações grafocêntricas. E quando este é apropriado pela oralidade, sua estrutura é tensionada e produz-se uma relação intersemiótica entre sistemas. Ana Mafalda Leite (2003) identifica a colagem, a fragmentação e a fusão como características dos "gêneros orais", , portanto, no momento em que a oralidade se apropria do romance, tende a fragmentá-lo e desorganizá-lo. Em Mayombe, Pepetela muda a voz da narrativa e dá espaço às considerações dos guerrilheiros no meio da trama.

\section{Luuanda}

O livro de contos Lunanda foi escrito em 1963, enquanto Luandino Vieira estava na prisão do Tarrafal. Luuanda é grafado deste modo para reforçar a forma de falar da cidade, remetendo à extensão do som à maneira da língua kimbundu. A escolha desta cidade como cenário tampouco é acidental: como já colocado, a maior parte dos militantes do MPLA vinha desta cidade, principalmente os grupos mais intelectualizados (como é o caso de Luandino).

No que diz respeito ao seu âmbito social, Lunanda é um livro composto por três "estórias", que retratam a vida cotidiana do musseque (zona residencial pobre de Luanda) nos tempos coloniais. No primeiro conto, expõe-se a real face da opressão colonial para quem vive no musseque e os problemas de se alienar desta realidade; o segundo trata de soluções à pobreza condenadas pelo mesmo sistema, o roubo, mas que não chegam a contestá-lo estruturalmente; e o terceiro aponta projetivamente para um novo modelo de solidariedade entre todos em que os

\footnotetext{
${ }^{7}$ A própria categoria "gênero" é insuficiente para designar os gêneros orais, uma vez que há uma relação porosa e incorporativa entre as diversas manifestações da tradição oral.
} 
mais jovens, a partir da atualização do saber trazido pelos mais antigos, solucionam o problema, vencendo, no final, a máxima "a cada um conforme sua necessidade".

Vavó Xíxi e seu neto Zeca Santos é uma estória atravessada pela privação, indicando justamente a ausência de perspectivas no final. O problema é que os dois personagens, cada um a seu modo, ao tentar negar individualmente esta vida de negações, acaba por reafirmá-la. Enquanto a Vavó Xíxi focava o passado, desejando retornar à antiga condição de crioula, o jovem olhava para o futuro, pretendendo o amor de Delfina (e nenhum dos dois se ocupava do presente). Ambos buscavam saídas individuais, alienando-se: a avó acreditava que poderia retornar à antiga posição caso o neto trabalhasse para ela e o jovem compraria uma camisa amarela, mesmo passando fome, para conquistar Delfina. O conto é inteiro pautado numa negação (até o amor de Delfina Zeca Santos perderia) e, no final, os dois definham, ou seja, ao afirmarem-se como indivíduos, esqueceram a relação existente entre eles (avó/neto, passado/futuro), e acabaram por negar sua própria condição de indivíduos, sucumbindo à fome.

O segundo conto, Estória do ladrão e do papagaio, não por um acaso intermediário, remete sempre a um espaço, tempo e personagens num entrelugar (aliás, é difícil saber, em alguns trechos, quando finda um tempo ou relato e começa o outro). Os lugares do conto são o musseque e a cadeia e o tempo corre do presente, na cadeia, para o passado, a história ocorrida no musseque. O futuro é tratado apenas em sonhos individuais: resolver-se com Kam'tuta para Dosreis, o amor de Inácia para Kam’tuta e livrar-se do peso da morte do amigo Felix para João Miguel. E os personagens até tentam negar a privação pela união, mas não acertam o conteúdo, comprometendo o próprio acordo existente entre eles. O roubo, ainda que feito coletivamente, é pautado por objetivos individuais e este é o motivo de a coletividade encontrar problemas para se colocar como tal. Dosreis e Kam'tuta, por fim, acabam presos (aliás, estabelecendo uma relação com o conto anterior, o pai de Zeca Santos/filho de vavó Xixi, figura intermediária, estava preso também, por razões políticas). Nenhum dos personagens tem um foco correto: Dosreis é consumido pela impressão de que Kam'tuta o denunciou sem provas para tal (e, quando pensa melhor sobre o que passou, percebe ter cometido uma injustiça); Kam'tuta acreditava que, roubando o papagaio, conseguiria ter o amor de Inácia, sem perceber que sua arrogância vinha do fato de ser uma assimilada; e João Miguel, por sua vez, recorria à diamba para fugir da culpa que sentia pela morte do antigo amigo Felix no passado. Deve-se destacar a irrupção da agressividade colocada na metade da estória: depois de um humilhante encontro com Inácia, Kam’tuta resolve não admitir mais que lhe provoquem por ser aleijado e, depois de ter ouvido a rejeição de Via Rápida, seu amigo, a que participasse do roubo, é acometido pela raiva e desfere-lhe um soco. Este despertar de Kam'tuta é positivo, já que se nota um rompimento com a ingenuidade anterior 
(partilhada por Zeca Santos), mas toma um foco errado, o papagaio. Garrido não entendia que o problema estava no sistema em si: no racismo estrutural ao colonialismo e na condição de assimilada de Inácia. Apesar de o conto demonstrar que esta falta de perspectivas corretas no conteúdo pudesse comprometer a própria coletividade, o final aponta para a união dentro da cadeia.

No meio do livro, Luandino faz uma reflexão sobre um cajueiro, símbolo do MPLA, emblemática para pensar a questão da resistência. Antes, já se coloca a relação de desenvolvimento que existe no fio da vida, os resquícios sempre existentes do velho no novo, e o tema da consciência, já que os pensamentos sempre têm que começar para quem procura saber. Ressalta-se no cajueiro o fato de ser velho, conforme a visão que põe em lugar central a experiência trazida pelos mais velhos para as novas gerações, e bom, pela sombra e pelos frutos, já que uma organização de resistência bem estruturada protege seus militantes da repressão e dá resultados concretos. A tentativa de destruição subsequente do cajueiro remete à ideia de que por mais que se tente acabar com a resistência eliminando fisicamente alguns daqueles que encampam sua causa, ela em si jamais acabará, pois o motivo de sua existência, a opressão, ainda existe. Aliás, as várias cores resultantes de sua queima são a representação das várias etnias que compõem uma mesma luta angolana, o cajueiro. O autor, então, faz a solicitação para que não se desça no caminho da raiz à busca do princípio, mas que "deixem o pensamento correr no fim, no fruto, que é outro princípio" (Vieira, 2006, pg. 60), tendo o fruto, aqui, dois papéis: o de resultado da produção do cajueiro (situação em que o avanço das forças produtivas leva a um entrave com as relações de produção) e o de um outro princípio, a sociedade transformada (estabelecimento de novas relações de produção depois da revolução social). No momento em que trata sobre o fruto como princípio desta nova sociedade, há um retorno no texto e a raiz do cajueiro, antes deixada de lado, ganha um novo destaque, evidenciando-se que seu princípio foi a semente antiga, ou seja, a noção de um avanço em espiral da sociedade: a nova formação social posta como resultado do desenvolvimento das contradições da sociedade anterior, a qual também resultaria de uma sociedade anterior e assim sucessivamente. Por fim, exorta-se a colocar esta questão na raiz das conversas, ou seja, a necessária conscientização para o desenvolvimento da resistência (a raiz do cajueiro).

O último conto, Estória da galinha e do ovo, tem um tempo projetivo e aponta para uma saída coletiva. A proposta da estória já é uma contradição em si. Tenta-se resolver em grupo uma questão de posse individual: a quem pertenceria, por "direito", o ovo. O problema é que cada uma das duas partes quer resolver a questão com base no direito de propriedade privada capitalista, ou seja, enquanto uma, Zefa, defendia que a galinha Cabíri (como se percebe, a ave 
não é individualizada, já que "cabíri” significa "galinha" em kimbundu) era sua, tendo ela o direito ao ovo, a outra, Bina, defendia ser ela quem alimentava a galinha e, botando esta um ovo em seu quintal, ele lhe pertencia. Aqui, a mais velha, vavó Bebeca, não consegue dar uma solução e diversos personagens são chamados para opinarem sobre o assunto. Cada um deles representa o discurso de uma instância da sociedade angolana - o comércio no caso do sô Zé, a Igreja por Azulinho, a propriedade imobiliária em sô Vitalino e o âmbito judiciário com sô Lemos -, sendo um por um rechaçados por proporem sempre soluções que visam o próprio interesse. A solução da querela não está no interior da sociedade, mas numa nova sociedade com outros valores. $\mathrm{O}$ sargento seria um personagem não convidado que acaba tomando para si não o ovo, mas a própria galinha pela força. A resolução se dá pelos jovens, não por acaso dois, que, aproveitando a tradição passada pelo mais-velho sô Petelu, por eles atualizada para o problema, fazem com que a galinha arranhe a repressão e voe para a liberdade. Nota-se aqui uma relação diferente entre os mais jovens (futuro) e os mais velhos (passado) do que nos dois primeiros contos: enquanto Vavó Xíxi e Zeca Santos estavam separados num primeiro caso, Kam’tuta e Dosreis eram tradicionalmente amigos, que tiveram um estremecimento na relação, mas que se uniriam no final. Aqui, não é nem necessária a figura do mais velho: Xico e Beto trazem consigo a tradição atualizada. Por fim, a solução encontrada não está no âmbito da disputa da propriedade, mas no campo da solidariedade para quem mais precisava (segundo a máxima "de cada um conforme sua capacidade, a cada um conforme sua necessidade"). O (n)ovo acaba ficando com Bina, já que estava grávida (futuro) e seu marido encontrava-se preso por atividades políticas (justamente, o pai do jovem, que se confunde com o novo tempo, é um comunista).

\section{Nós, os do Makulusu}

O romance Nós, os do Makulusu, escrito em 1967 e publicado em 1975, trata da trajetória de um personagem, o Mais-Velho, no dia do enterro de seu irmão, Maninho. A morte deste representaria, entretanto, um evento traumático para aquele, dilacerando sua consciência. O resultado é a apresentação dos acontecimentos do dia - do caminho percorrido pelas ruas de Luanda até o enterro - por este personagem-narrador a partir de uma narrativa fragmentada, própria de uma mente perturbada, que fundiria o presente a recordações do passado e perspectivas futuras. Tal realidade espacial e temporalmente estilhaçada pela violência remete não somente à figura individual do Mais-Velho, mas à sociedade angolana como um todo, também consumida na luta anticolonial. Luandino, mesmo que envolvido diretamente com o MPLA e 
preso por isso no Tarrafal, propõe aqui um questionamento profundo à viabilidade de construção de um projeto social de futuro, diante do grande choque social representado pela guerra.

O personagem-narrador, Mais-Velho, é um intelectual engajado com a causa de libertação em Angola, um colonialista que se recusa, como expressou Memmi (1967). Apesar do orgulho que sente por Luanda, como se expressa nas ofensas dirigidas à irmã que queria justamente esconder sua origem, não compartilha dos hábitos locais: prefere bacalhau à galinha e evitava deitar-se com mulatas ou negras para não parecer ser um colono aproveitador, ainda que sentisse atração pela companheira do irmão, Rute. Mais-Velho é muito escrupuloso: apesar da militância política anticolonial, sua característica principal é o imobilismo. Como denuncia Maninho, sua ideologia é mais uma moral, uma vez que sua ação é condicionada sempre pela certeza: "Este sou eu, o matemático, o objectivo, quem quer ter certezas, que vi e mando" (VIEIRA, 2008, pag. 44). Pode-se dizer que este é o retrato não somente de um indivíduo, mas do intelectual de esquerda em geral. Suas vacilações e seus costumes fazem parte daquilo que Memmi denominou "dança atormentada do colonizador que se recusa": entende as contradições da política colonial, mas não se identifica com a classe que defende e, muitas vezes, não compactua com suas táticas. Este último não é o caso de Mais-Velho, como se coloca no trecho:

“A mãe dizia: 'terroristas', eu queria emendar, queria desviar o coro das vizinhas dando pêsames e o choro silencioso da mãe, e dizer: guerrilheiro - mas ninguém que me percebia, eu não falava a mesma língua que elas, elas diziam terrorista e, naquela hora, queriam dizer morte só, e eu queria fazer discriminações na morte, classificar mortes e elas não: terrorista, guerrilheiro, guerra, morte, tudo era o mesmo naquela hora, o buraquinho cu d'agulha por onde que fungou o fino óvulo chocado no útero que minha mãe já carrega nove meses e ia parir entre gritos e dores, nuns minutos se sumia com a mãe entre gritos e dores" (VIEIRA, 2008, pg. 30).

Maninho, pelo contrário, é um personagem de grande ímpeto. Desde pequeno aprecia a comida local, deita-se com as angolanas e sai para as festas. Apesar do seu posto de alferes e da mentalidade "matar on morrer, ir on recusar-se - são as quatro estaçôes" (VIEIRA, 2008, pag. 88), Maninho interessa-se por Rute, sua namorada mulata, quando esta liberta da gaiola os pássaros que Kibiaka vendia. Sua opção de ir para a guerra ao lado das tropas colonialistas se deve muito mais a uma atração pela ação do que a uma convicção política real, uma vez que seus valores são profundamente humanistas. Considerava a atividade política do Mais-Velho um papaguear inútil sobre a Argélia e uma inócua distribuição de panfletos, instando-o, por isso, a pegar em armas e defender suas convicções na prática. 
A morte do personagem que representa a ação relatada já no começo do livro é muito simbólica. Refere-se à própria estrutura narrativa do romance, baseado não tanto em ações, e sim na apreensão fragmentada do real por uma consciência traumatizada. Sua morte mesma é contraditória: não somente porque o personagem de grande vivacidade parecia feliz, como também pelo fato de, apesar de estar morto e por causa disso, definir, pelo trauma causado no irmão, toda a estrutura do romance. É como o próprio sistema colonial: embora já estivesse "morto", consumido na violência do conflito, fazia-se ainda presente, traumatizando a sociedade angolana. Em outros termos, a impossibilidade de expressão do Mais-Velho, causada pela violência do assassinato de seu irmão, seria a mesma vivida pelo país, marcado indelevelmente pela guerra.

Aliás, assim como o colonialismo, os personagens do romance são marcados por profundas contradições internas: a mãe, uma boa colona, que trata os africanos por "senhor"; o operário Brito, fundamental na formação política de esquerda do Mais-Velho, mas que mataria um jovem negro na rua; um sô Paulo racista, que jantava à mesa com o professor negro dos filhos etc.

Os outros dois do Makulusu são Paizinho e Kibiaka: o primeiro é o meio-irmão mulato de Maninho e Mais-Velho e o segundo é um angolano. Paizinho seria preso no momento em que, violando as normas de segurança da organização, Mais-Velho iria para a sua casa contar sobre o assassinato de Maninho. A figura intermediária de Paizinho, meio-irmão e mulato, lembra um pouco a condição de um personagem ausente no primeiro conto de Luuanda, o pai de Zeca Santos e filho de Vavó Xíxi, preso justamente por “terrorismo” e, de certa forma, a própria condição de Luandino, meio-português e meio-angolano, detido no Tarrafal. Kibiaka, por sua vez, era um angolano digno que teve que fugir justamente por agredir o seu chefe, um comerciante branco que insultou sua irmã. Esta reação remete à reflexão de Fanon sobre a violência como libertação do africano no colonialismo. O fim dos três outros personagens que compunham o grupo do Makulusu leva Mais-Velho a reconhecer que ele foi o único que sobrou.

A Luanda colonial é retratada como um espaço da opressão e da desigualdade, algo evidente no assassinato, ocorrido na rua, de um jovem negro pelo operário Brito, estimulado por um grupo de brancos ou na frase de Maninho "lavar o sangue dos escravos com o mijo dos patrões" (VIEIRA, 2008, pag. 34), enquanto urinava na rua. Sobre o assassinato do jovem, cabe recordar a reflexão de Memmi sobre a condição do colonizado nesta sociedade: "uma vez que o colonizado é presumido ladrão, é preciso prevenir-se efetivamente contra ele; suspeito por definição, por que não seria culpado?" (MEMMI, 1967, pag. 85). Outro elemento colocado é a relação com a terra africana: a irmã, única da família (oficial, não contando o Paizinho) a ter nascido em Luanda, envergonhava-se de sua 
origem e relata, com prazer, a alteração de seu registro de nascimento em Portugal. Os do Makulusu, pelo contrário, firmam um pacto de união na caverna do Makokaloji, sob a terra. Aliás, Makulusu é um topônimo kimbundu, nome de um antigo musseque de Luanda, que significa “cruzes”, defendendo José Cesar de Paula (2011) ter Maninho percorrido uma Via Crúcis no decorrer do livro (até o Cemitério do Alto das Cruzes).

\section{Mayombe}

O romance Mayombe foi escrito em 1971, mas publicado somente em 1980. É a história de um grupo de guerrilheiros do MPLA nas selvas do Mayombe, em Cabinda, onde se encontrava a $2^{a}$ Região Político-Militar da organização. Pepetela expõe que, mesmo entre guerrilheiros engajados na luta anticolonial, existiam problemas como o tribalismo, entendido como um fenômeno rural, e discordâncias profundas que, muitas vezes, partiam de questões meramente individuais.

O marxismo-leninismo é problematizado pelo próprio Comandante, uma das figuras centrais, que prefere, em muitos casos, adotar uma perspectiva mais subjetiva, despertando a desconfiança de guerrilheiros que faziam leituras mais dogmáticas, como Mundo Novo, por exemplo. Este chega a considerar que "o Comandante não passa, no fundo, dum diletante pequeno-burguês, com rasgos anarquistas" ou "o futuro ver-me-á, pois, apoiar os elementos proletários contra este intelectual que, à força de arriscar a vida por rąõos subjectivas subiu a Comandante" (PEPETELA, 1993, pags. 117 e 118). Por ter uma formação religiosa, o Comandante Sem Medo questiona a absolutização da teoria e toma frequentemente medidas consideradas heterodoxas. Numa passagem, resolveu conversar com dois guerrilheiros depois de ver o comportamento das nuvens no céu: embora não seja uma atitude muito marxista, está estreitamente relacionada com o entendimento da unidade entre tempo, espaço e sociedade, presente em Luuanda, por exemplo. Ele condena ainda o que entende ser uma religiosidade dos quadros do movimento e postula questionamentos interessantes sobre o socialismo, ainda que entendesse que era o único a ser feito. De qualquer forma, enfatiza sempre que não teria lugar numa sociedade socialista, tal como o colonizador de esquerda para Memmi, guardada a devida distância, luta por algo que crê justo, mas desconfia que não terá muito espaço num novo sistema político.

Como já mencionado, apesar do internacionalismo proletário defendido pelo MPLA, o tribalismo aparece como elemento de destaque mesmo entre os combatentes do movimento, ainda mais pelo pouco apoio da população local à guerrilha. Discussões do comando e missões político-militares acabavam por conduzir a conversa e as avaliações dos guerrilheiros, a não ser 
dos chamados "destribalizados", para este campo. Em momentos de dificuldade, a própria direção evitava castigos e comportava-se mais como mediadora dos conflitos tribais do que os coibia de fato. O romance termina, inclusive, com uma mensagem pedagógica neste sentido, colocada pelo Chefe de Operações: "Lutamos, que era cabinda, morreu para salvar um kimbundo. Sem Medo, que era kikongo, morreu para salvar um kimbundo. É uma grande lição para nós, camaradas". Palavras estas confirmadas por Milagre: "Foi um grande Comandante! E Lutamos um bom combatente?" (PEPETELA, 1993, pags. 283 e 284). Não foi casual a escolha dos personagens: o primeiro partilharia da desconfiança contra o guerrilheiro Lutamos durante toda a narrativa (também por ter participado dos massacres da UPA de março de 1961) e o último era quem, desde o início, mais levantava o tribalismo (chegaria a defender que as tribos mais avançadas deveriam dirigir outras). A própria imagem final da mistura entre as folhas de mafumeira e as folhas verdes remete à necessária superação deste tipo de divergências (e a ideia de que "o Mayombe recuperaria o que os homens ousaram tirar-lhe" pode ser lida em dois sentidos: a paz na selva e a reconciliação entre os grupos separados pela política “dividir para imperar”).

Em Mayombe, há um narrador onisciente que se refere aos eventos em terceira pessoa e, por isso, não há muitas suspeitas quanto à história contada e às características dos personagens. Em alguns trechos, estes conduzem a narrativa, interpretando eventos políticos a partir de seus valores e concepções pessoais. Entretanto, em nenhum caso, este “direito à voz" deixa margem a uma interpretação sobre o caráter dos militantes que afronte a perspectiva já desenhada pelo narrador onisciente. De qualquer forma, tal recurso amplia a compreensão sobre alguns guerrilheiros, permitindo até a relativização de algumas de suas atitudes. O Chefe de Operações, por exemplo, revela sua dificuldade em conversar com Sem Medo por este ser um intelectual e aquele um camponês - e talvez esta origem de classe seja também a explicação de sua ressalva em relação ao Comissário, figura de forte formação política.

Quanto aos intelectuais, grupo social relevante no MPLA e condição do próprio escritor, os personagens que mais representam este papel no livro são Mundo Novo e o professor Teoria. Este era um mestiço e lutava para garantir o espaço do "talvez" num mundo maniqueísta, mas, como intelectual, exagerava o medo que sempre sentia. Mundo Novo, por sua vez, ascende à direção no decorrer da narrativa, mas era um militante jovem e dogmático e, por isso, defendia uma disciplina mais rígida do que o próprio comando, principalmente em momentos de crise. Em conversa com o Comissário, Sem Medo atenta ao equívoco de proclamar um partido dominado por intelectuais revolucionários como um partido proletário, pois tal mentira suscitaria desconfiança e desmobilizaria os trabalhadores. Pepetela problematiza esta figura social, vista com desconfiança por guerrilheiros de origem camponesa, mas de fundamental importância, já 
que é impossível uma atuação revolucionária sem formação política nem entendimento aprofundado sobre as contradições sociais (além disso, eram os intelectuais que combatiam o tribalismo no movimento). Esta relação dúbia se expressa inclusive na utilização da palavra: o Chefe de Operações e Milagre utilizam-na pejorativamente, com o sentido de pequeno-burguês, e o próprio André é descrito como "intelectual-aristocrata", mas, em diversos trechos, sua relevância num movimento de contestação ao colonialismo e edificação de uma nova sociedade é reconhecida.

Diferentemente de Luandino, em que contradições antagônicas dos personagens impedem uma identificação emocional com a história, criando assim um estranhamento por parte do leitor, em Pepetela essa aproximação está presente. Além disso, enquanto o primeiro enfatiza, pela própria fase da resistência, os elementos sociais nos personagens, o segundo põe em relevo os aspectos individuais presentes na guerrilha. Como coloca o comandante Sem Medo, "tens de te habituar aos homens e não aos ideais" (PEPETELA, 1993, pag. 23).

\section{CONCLUSÃO}

De acordo com Ana Mafalda Leite, "a reivindicaşão africana é, no seu início, marcada ideologicamente pela ideia nacionalista, que se rege pela nostalgia de uma percep̧cão emocional unificante e que, por seu turno, se identifica com a ideia de uma estética fundamentada nos registros pré-coloniais das culturas africanas orais" (LEITE, 2003, pag. 36). Com efeito, a literatura de afirmação nacional, ainda que inacessível à maior parte dos colonizados, foi de fundamental importância para a unificação política em torno de um projeto e de uma língua, a do colonizador, oraturizada. Estes escritores, inseridos num ambiente urbano e de opressão, estabeleceram um profundo diálogo com a produção teórica antiimperialista e terceiro-mundista, em voga num contexto de descolonização no continente. Em 1975, Angola tornou-se independente e o MPLA anunciou o caráter socialista do país, entretanto a africanização da guerra anticolonial realizada pelos portugueses traria sérios problemas para a unidade interna e levaria a uma guerra civil que se arrastaria até 2002, ano da morte de Jonas Savimbi, da Unita. Além do mais, o contexto internacional já não favorecia o bloco socialista e os países de Terceiro Mundo como nos anos 1960 e início dos 1970. Afinal, os soviéticos enfrentariam a estagnação e os ianques estavam em processo de recuperação da crise do dólar e do petróleo. Estes fatores comprometeriam seriamente o projeto político antes advogado e levariam a que muitos desta geração de "heróis nacionais" se tornassem, no dizer do próprio Pepetela, "predadores". 


\section{REFERÊNCIAS BIBLIOGRÁFICAS}

ANDERSON, Perry. Portugal e o fim do ultracolonialismo, Editora Civilização Brasileira. Rio de Janeiro, 1966.

BALANDIER, Georges. A noção de situação colonial. In: Cadernos de Campo Revista dos alunos de Pós-Graduação em Antropologia da USP, n 3, ano III, 1993.

BITTENCOURT, Marcelo. Dos jornais às armas - Trajectórias da contestação angolana. Vega Editora. Lisboa, 1999.

BITTENCOURT, Marcelo. "Estamos juntos!" - O MPLA e a luta anticolonial [1961-1974]. Volume 1. Editora Kilombelombe. Luanda, 2008.

CANDIDO, Antonio. A educação pela noite \&o outros ensaios, Ed. Ática. São Paulo, 1989.

CÉSAIRE, Aimé. Discurso sobre o colonialismo. Cadernos para o diálogo. Porto, 1971.

CHAVES, Rita \& CABAÇO, José Luís. Frantz Fanon: colonialismo, violência e identidade cultural. In: ABDALA JR., Benjamin. Margens da cultura: mestiçagens, hibridismo e outras misturas. Editora Boitempo. São Paulo, 2004.

FANON, Frantz. Os condenados da terra, Editora UFJF. Juiz de Fora, 2006.

GIAP, Vo Nguyen. O Vietnam segundo Giap, Editora Saga. Rio de Janeiro, 1968.

HERNANDEZ, Leila Maria Gonçalves Leite. A África na sala de aula: visita à História Contemporânea. Editora Selo Negro. São Paulo, 2005.

LEITE, Ana Mafalda. Literaturas africanas e formulações pós-coloniais, Ed. Colibri. Lisboa, 2003.

LENINE, Vladimir Ilitch. Obras escolhidas - Volume 1, Editora Alfa-Ômega. São Paulo, 1979.

MEMMI, Albert. Retrato do colonizado precedido pelo retrato do colonizador, Editora Paz e Terra, Rio de Janeiro, 1967.

MINH, Ho Chi. La cuestion colonial - Escritos periodisticos (1922-1926), Biblioteca Proletaria. Ediciones Compañero. Buenos Aires, 1971.

N'KRUMAH, Kwame. Neocolonialismo, último estágio do imperialismo, Editora Civilização Brasileira. Rio de Janeiro, 1967.

MONTEIRO, Manuel Rui. Eu e o outro - o invasor (ou em três poucas linhas uma maneira de pensar o texto). In: MEDINA, Cremilda. Sonha, mamana Africa, Epopeia. São Paulo, 1987.

de PAULA, Julio Cesar Machado. Luandino Vieira e as encruzilhadas do Makulusu. Nau literária: crítica e teoria de literaturas em língua portuguesa, UFRGS, Volume 7, Número 1, Jan-Jun 
2011. http://seer.ufrgs.br/NauLiteraria/article/view/20442/13335. Acessado a 07 de dezembro de 2011.

PEPETELA. Mayombe, Publicações Dom Quixote. Lisboa, 1993.

SERRANO, Carlos. A trajetória da elite intelectual, a "geração de 50" e seus projetos: a nação. In: CARDOSO, Carlos; ARAÚJO, Manuel G. Mendes de; e SILVA, Teresa Cruz e (orgs.). "Lusofonia” em Africa: História, democracia e integração africana, Codesria. Dakar, 2005.

STALIN, Joseph. Questões políticas, Editora Aldeia Global. Belo Horizonte, 1979.

VEIGA, Luiz Maria. Retratos do colono, do colonizador, do cidadão: a representação literária da minoria branca em Nós, os do Makulusu e em outras narrativas angolanas. 2010. 293f. Dissertação (Mestrado em Estudos Comparados de Literatura em Língua Portuguesa) - Faculdade de Filosofia, Letras e Ciências Humanas, Universidade de São Paulo, São Paulo

VIEIRA, José Luandino. Luuanda, Ed. Companhia das Letras. São Paulo, 2006. . Nós, os do Makulusu, Edições Cotovia. Lisboa, 2008. 